\title{
dE/dx ELECTRONICS FOR MARK II EXPERIMENT AT SLAC-
}

\author{
D. Branstem, A. Boyaget, D. Coupal, G. Felduar and L. Paffratu
}

Stanford Lineor Aceelenator Center

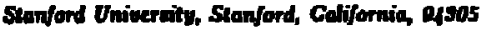

\begin{abstract}
Abatratt

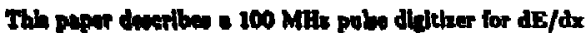

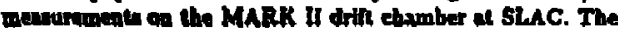

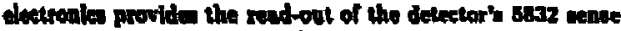

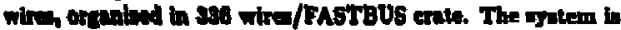
baed on a 14-hand FASTBUS aodele. The bak element of the andule in the TRW G-bit Fich-ADC.
\end{abstract}

\section{Introduction}

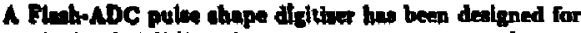
we on the MARK H/sLC lave volume drift ehamber.'

The dritt chanber conalnte of a ceries of cells arranged in 12 eyllndrienl layors with wise in the axial disection and with exh edll havians sanen wires. Figure 1 hows the geometry of

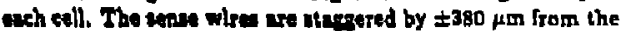
unse win midplane to slow edeulation of which side of the eoll wa travarad by the irack. Fech wise in inotrumented with - prenopllet at the ehamber feed-1hrough, 20 feet of aignal eable ladins to sont-ampilf ar with gole-sero fiter, and then 80 font of twisted-pait eablo laediag to BADC module.

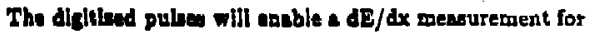
particle Identifention and alo complement the drift time meauurumants of 2 are tme resolution TDC system. The digitimition ta parformed at 100 MSPS wing a E-bit TRW 1029J7C convarter. Thls wection 15 the result of comparing the availablo FADC's and COD' on the buis of overall performance, powat divipation, cost and pectuging.

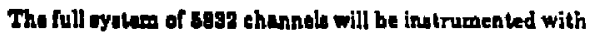
16-chnnel FAST IUS modula.

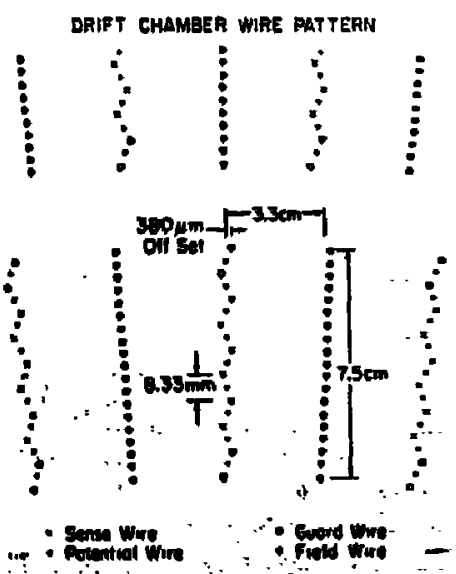

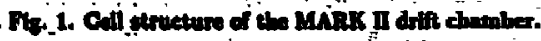

- Work oupportad by hite Depurtment of Energs, contract De-Acos-7aspoosis.

\section{dE/dx Syatem Orgenintion}

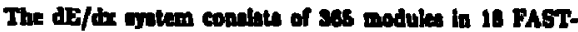

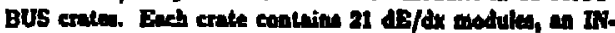

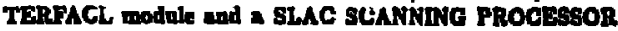
(SSP).

The INTERFACB module, whilh weepte NM pules throuth the frant panel, atred the bectoplane of the RAST. BUS crate in diferential ECL hejic. If dwo provides - on the front panel - $21 \mathrm{NM}$ lagic fanouts for $100 \mathrm{MEl}$ eloct.

One SYSTEM CONTROLLER wapplin tha required cleck puloes - IOS Mhe and $10 \mathrm{MH}$ - and coateol aloalh to all 18 Interface modules in the aystetm, we Fis. 2.

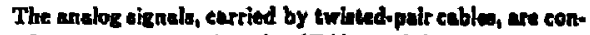
nected to the frant panel of the $d E / d x$ module.

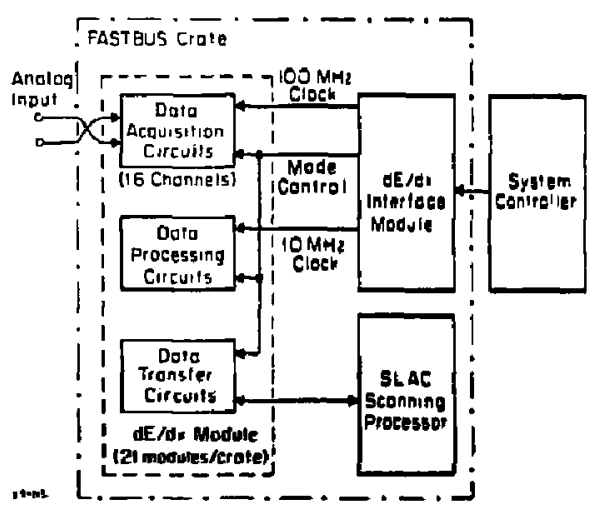

Fic $2 \mathrm{dE} / \mathrm{dx}$ Syatea: block dingrem.

\section{dE/Ax Module}

The dE/th module in is abots whb PASTBus moding

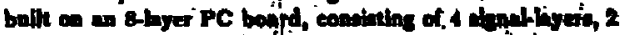

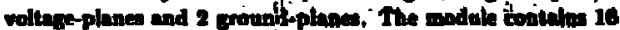

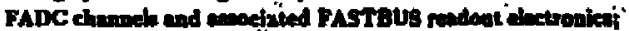

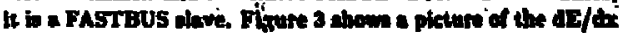
module. The frome-end etevpien about ean-thind of the PC

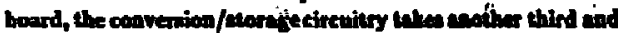

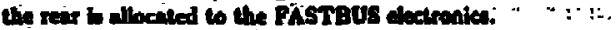

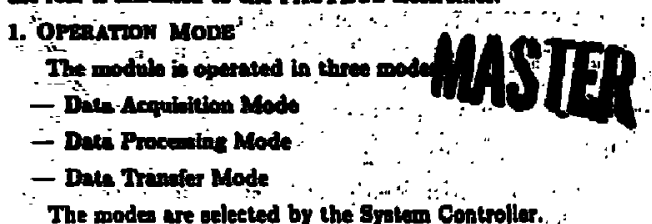

The mode are enleted by the spolem Conterlier. 


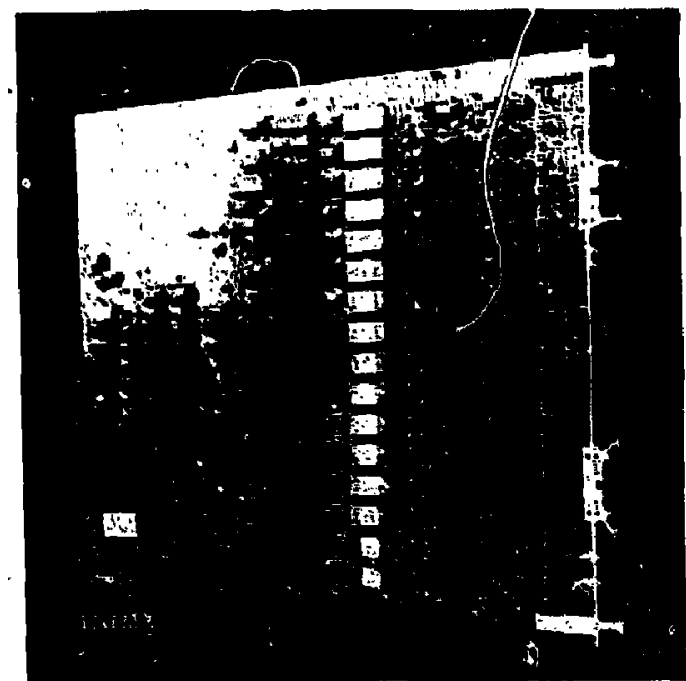

Fin. 8 . View of the dE/dx module.

\subsection{Date Acqubltion Mode}

In this modo the Data Memory for anch of the 16 channels is ensbled and the analog signels are digitized and stored into $256 \times 4$ ECL-memories. Ono-half of thels cepseity is used because, in our ense, the drith time is las than 1.28 meec. The module is elocked by an external $100 \mathrm{MHz}$ clock which cen be either oynchronised to the beam erosing time or aynchronous for ecomic ray data ecquisition.

\subsection{Data Procesing Mode}

Zero mppreation is cehioved through en Internel data procesoint eycle which records channel number and memory oddres for non-enpty date. In thin mode, 16 Data Memprie are ceanned at 10 MHs; 8 higher frequency is poesible if necenary. This ecanning requiles 208 pax. Pach of the 128

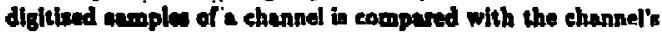
4bit thrahold value wered in the Threhold Mariory (16 $\times 4$ ). The addreas correaponding to the frot eample above the threahold, whleh merles the leading edge of the dimel, and the bat cumple chowe threahold, which must the tralling odge of the

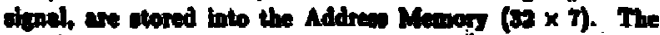

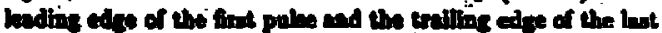

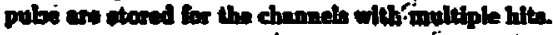

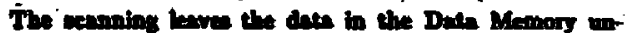
changed.

\subsection{Daen Irenter Mode}

All three wote of memoile (Dath, Throhold and Addrens) are secenad by the 8BP, loeated in each erate. Rondom trano-

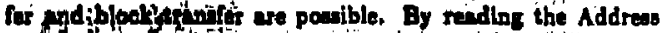

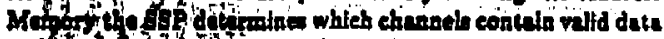

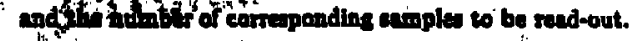

\section{Chour Desonipion}

$\therefore$. Followling th a bridf d-aription of eome circuit dealgin ab

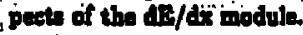

A unity-gain front-end diffesential amplifer reeivea analog aignals and drives through an emitter follower the input impedance of the FADC, see Fig. 4. This impedance is voltage dependent. Therefore, a 51 ohm termination provides the front-end amplifier with copatant load, Independent of the fluctuatione of the FADC's input impedanee. It also decreases the RF pick-up.

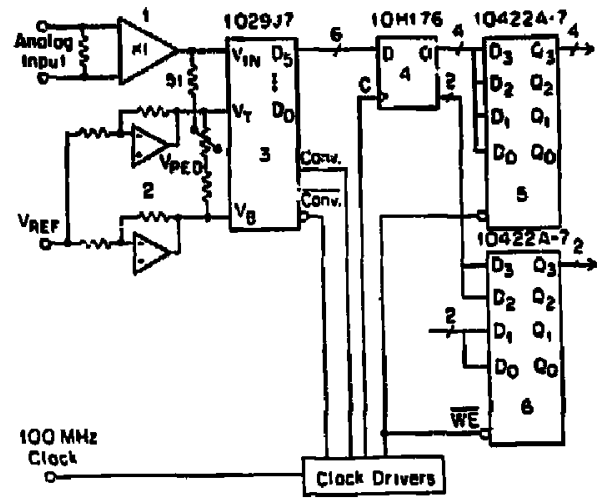

I-ChanNel LaYout

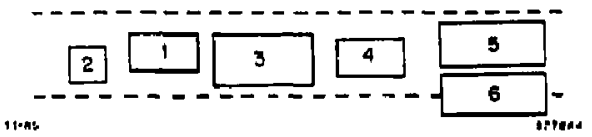

Fig- 4. Analog-to-Digital convervion: simplifind block diegram.

The anales to digital converion is Ineas. Fich channel's FADC i bisud by a dual ap-amp driven by a reference voltage source in order to reduce the crove-talk batwen the 16 channela and the RF pich-up. One reference valtage souree is provided per 8 chnnnels. The podeatals are adjutted manually.

The derigm wes originally based on 10 naee access time memory. A G-bit fal bufter regioler was provided between the FADC and ECL-metpory in order to gursentea the conversion at 100 MSPS. Currantly the module are equipped with 7 nuec acess time ECL memory which slows conversion at rute up to 140 MEPS. A layout of the channed in aloo thown to Rts. 4.

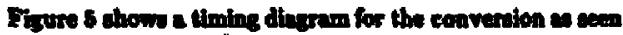

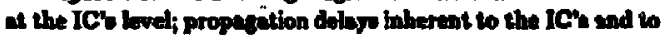
the tranpi ion lines of different lergthe are not thom. These

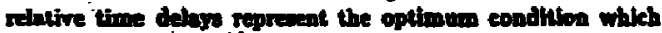
should be culinfied on ech of the 16 chanoth of the moduli. Therefore the decigne was intended to avoid the necentity of delay adjutments for each individual chennel. In order to achieve this goal, the $\mathbf{1 6}$ channels are organized in four eroups with fidenticel leyout. This approach allow us:

- to anse the drive requirements.

- to reduee the longth of the transmbaton lines for the aumerous functions involved in the eonvarion/storage procesto.

- to presierve the rolutive time delare botwen the FADCh otrobe (CONV \& EOWV), Bufiar Reginter' elack. (C), 

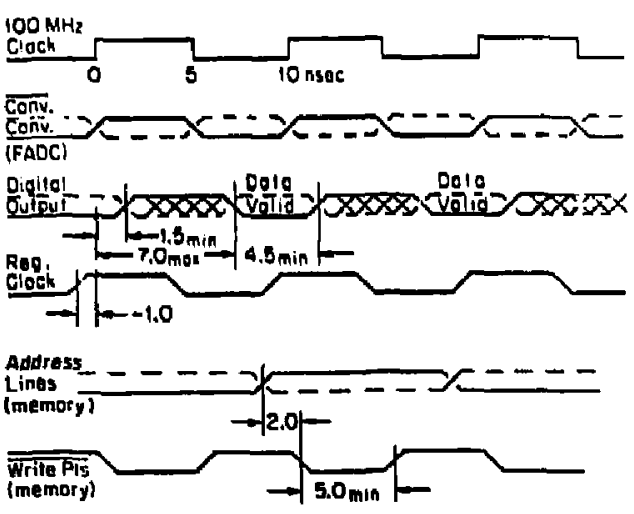

$11 \cdot 85$

sataAs

Fis. 5. Anslog-to-Digital converaion: timing diagram.

Memory's writing pules (W5) and the Memory's Addresslines.

There is a provition to adjust the relative time delays between the conversion pulen (FADC), the elock pulses (Buffer Regiater), the Write Enable pulses and Address lines (Data Memoriea) which are common to all 16 chnnnele.

Given the large aize of a FASTBUS PC board, a time delay gradient axrose the board is unavoidable; the soltware should correct this for time mesurements.

The Data Memory output are wire-ORed, buffered and connected to the FASTBUS AD-lines.

The Address Memory ( $32 \times 7$ ) is organized in a lower-half which storms the addreas of the first sample sbove the throahold and the upper-hall which storen the address of the lest asmple above the threhald. In the Dite Procening Mode, a digithl comparator ensbles o write cycle in the Addreas Memory if the sample value is above the threahold value stoted in the Threshold Memory. As a roult, the addreas correaponding to this aperific cample is written into the Addrea Memory, ece Fig. 6. Bafore weanning any of the 16 channela the Addreas Memory in eleared.

As a EASTBUS plave, the module hes been provided with the following functions: reoprephieal addresing to CSR-space and DATA space, CBR $\# 0$, cecondury iddrasting, random or block transfers.

The NTA regiter he ofwo-fold function:

- when loaded by the muter, it addreses one of the three memory oets implomented in the module.

- when elocked during Data Acquinition of Dets Proceasing it is uad as the module's Address Counter.

For debugging purposed a 100 MHI-DAC, which can be pluged in the provided secket, follows the tonverted algnal on-line. The anales almal is onallable on the front panel. For the anme rawon; $10 \mathrm{MBZ}$, clock can be plugged in the board to provide an internal source for the It Mine Deta Procesing clock.

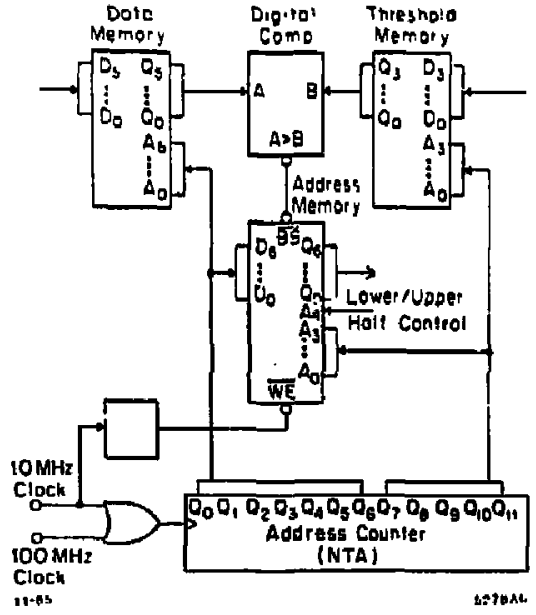

Fjg. 6. Data Procesaing: dimplified block diagram.

\section{Measuremente and Performance}

A full FASTBUS crate of FADC modules was recently connected to the MARK II/SLC drift chumber to be tested with cosmic rays. Two gas mixture were used in the test. One was HRS gas, a mixture of $89 \%$ Argon, $10 \% \mathrm{CO}_{2,}$ and $1 \%$ Methene with a drift velocity of $52 \mu \mathrm{m} /$ neec and the other a elightly different mixture which gave alower velocity of $33 \mu \mathrm{m} / \mathrm{ruec}$. Some preliminary tindings can be presented bere;

- Pulae Shspe: an average pulese shope is ahown in Fig. 7 . The average pulse shape wan delermined by adding pulses from many track; it has a width of about 50 noes FWHM. Figure 8 shows aetual pubes froca 8 wires in one cell as recorded by the FADC system. This corresponds to a track along the middle of a cell.

- Linearity; the non-linearity in the messurement of the pulse ares was found $t o$ be leas then 2\%.

- Treck Separation: Figure o ahow pulse train for the 6 wite in one cell resorded by the FADC artem. This correspondo to two tracks in one cell. Two track

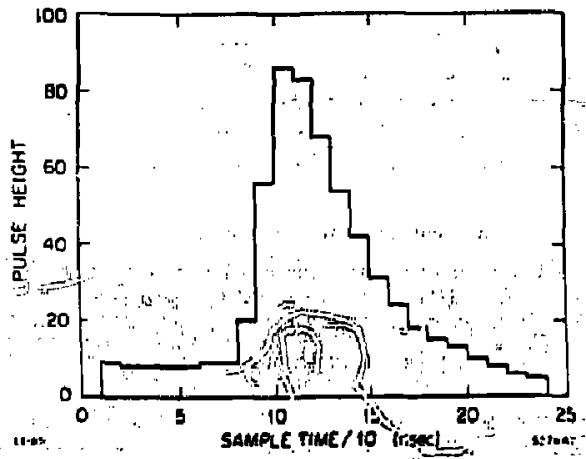

Fig. 7. FADC pulae shepet arerage puile for BRS ges. 


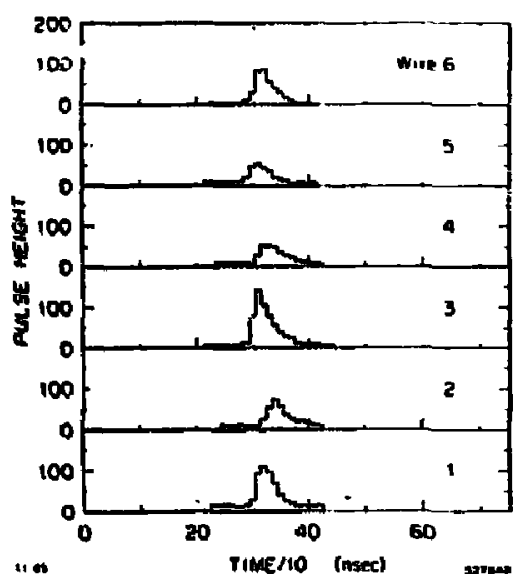

Fh. 2. PADC date: angle tracts through one cell.

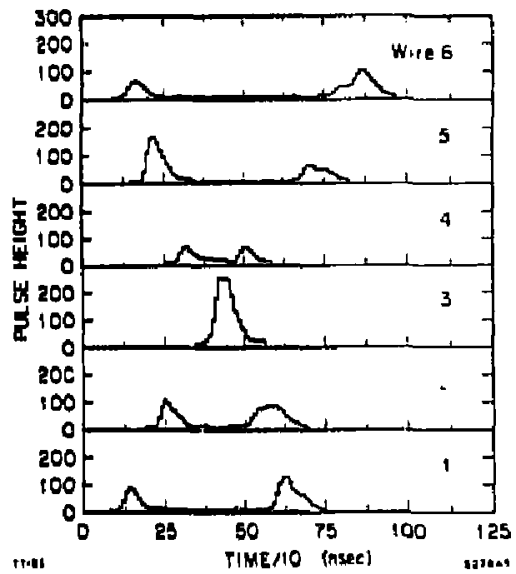

Fis. 9. FADC data: double track through one cell.

separation in atill belng studled but nimul htinn. mugseat one shonld cehiove separationo of beter them $3 \mathrm{~mm}$.

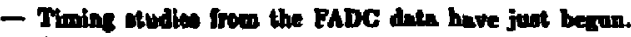
A cfimple llowthm which fad the leating edge by ex-

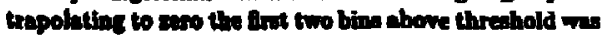
thed for the time ansurement of a pulbe. The tining

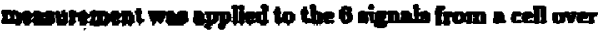
mus tredo to provide timing periormance for real truels

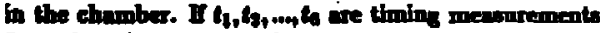
from the ath whes, then the cunatity

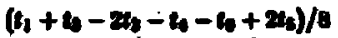

fres the tim to turawe the $\pm 000 \mathrm{~mm}$ etagger in the wane wise Fow 10 shime this dintribution. The

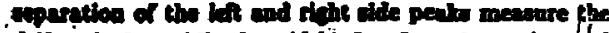

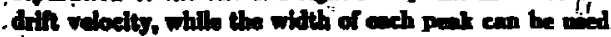

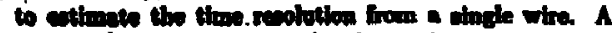

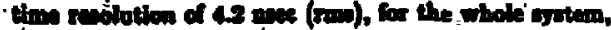

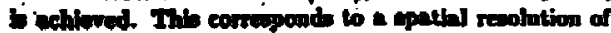

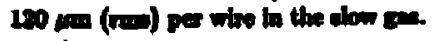

$A$ aceond Igorithm wring the centroid of the frat threp bins nbove the threshold yields a eimilar realution. The intrinvic renolvtion of the dE/dx electronice only to leas than 2.9 natex.

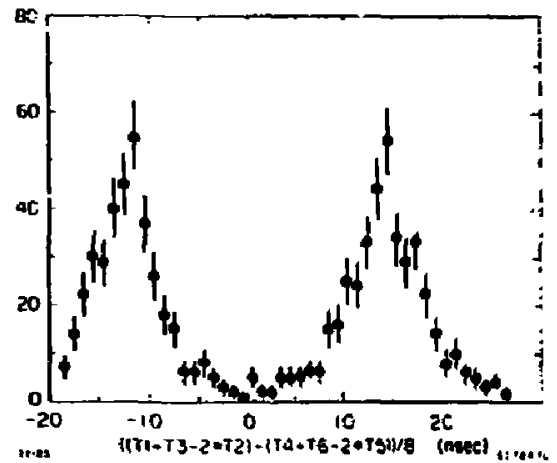

Fig. 10. Double peak distrlbution in slow gas.

The 16-chunnel FADC module he been teated. For the front end amplitier, the menurementa performed on 16 chan. nels show that gains are within $\pm 3 \%$, nonlinearity is len than $2 \%$ of full range and croas-talt is leas than $1 \%$. Temperature dependence of the pedestala was measured to bo $0.2 \mathrm{LEB} / 10^{\circ} \mathrm{C}$. The rise and fall time are 12 nuec. The specifieations of the module are given in Table 1.

Table I. Technieal Spesifiestion:

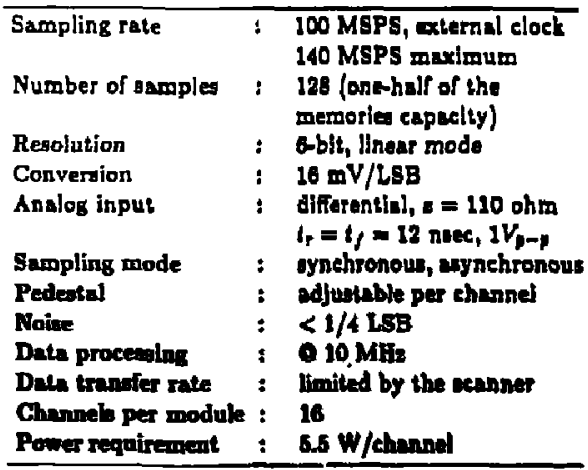

\section{Acknowledigenente}

We widh to ackoowledge the mintance of P. Ranktin and

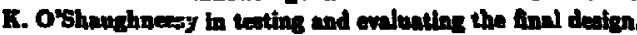

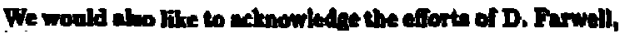
R. Mintheon, J. Turlor, D. Andres and P. Martin in tutting 140 $\mathrm{dB} / \mathrm{dx}$ wodulea for $1 / 3$ of the extem.

\section{Rifomence}

1. "Proponal for the Mark II at SLAC," CALTCam1018, DOE Revanch ind Developreat Proponal, April 190.

2. D. Briag et 4 , The BuAC Mark II Uporde Drth

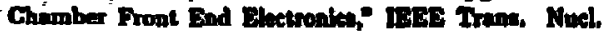
Sci., Vol. NS-g2, No. 1, Rebruary $19 e x$. 